\title{
UN LIBRO IMPORTANTE VIDAS PÚBLICAS, SECRETOS PRIVADOS
}

\author{
Jorge Isaac Zamudio Franco ${ }^{\star}$
}

Twinan, Ann. (2009). Vidas públicas, secretos privados. Traducción de Cecilia Inés Restrepo. Buenos Aires: Ed. Fondo de Cultura Económica, 500 páginas.

La historia de la Colonia en América Latina ha sido magistralmente estudiada por especialistas como David Brading en La primera América (1991), Anthony Macfarlane en Colombia antes de la Independencia (1997), y Jacques A. Barbier en Reforma y políticas en el período Borbón. Chile 1788 - 1796 (1980). Sin embargo, ha sido poco cultivado el tema de la familia y la sociedad; de ahí que el historiador tenga que armar su cronología y sus temas casi de cero. He aquí un libro original en cuanto a temas, fuentes y enfoque. En Vidas públicas, secretos privados Ann Twinan no aborda la cuestión de la legitimidad y la raza de manera aislada, sino como estrechamente ligada a la cultura e inmersa en la sociedad. El manejo que da a las referencias teóricas diseñadas alrededor del concepto de género y sexo es asequible y amable con el lector. Twinan nació en 1946 e hizo un doctorado en la Universidad de Yale; en la actualidad vive y trabaja en Austin y es profesora de la Universidad de Texas. Esta historiadora escribió un bello y útil libro sobre Antioquia, titulado Mineros, comerciantes y labradores, las raíces del espíritu empresarial en Antioquia, $1763-1810$ (1982).

Tradicionalmente la Colonia fue vista como un período por lo demás difícil, con mucho control racial y moral, y sin cierta movilidad social. La autora observa que los hijos naturales, ilegítimos, adulterinos, incestuosos y sacrílegos proliferaban, y que a menudo sus padres para efectos de la herencia y honor, trataban de legitimarlos ante el Consejo de Indias. Esto es una historia de las élites. Este libro importante estudia también cómo las élites se percibían unas a otras, en los acercamientos e intercambios de valores, vistas desde las rutinas cotidianas.

Este libro es un brillante recuento del período de Austria y lo que es más importante, del período de los Borbones; la autora, sin desconocer la intolerancia y la intransigencia del catolicismo hispanoamericano o los limitantes efectos de la romanización, muestra cómo la Colonia era una sociedad racista, donde un negro, un indio o un mulato no podían estudiar en los colegios mayores, ni muchísimo menos en la Universidad, donde se exigía limpieza de sangre y en donde no existían matrimonios entre las élites y las castas, lo cual era prohibido, hasta tal punto que las élites construían barricadas sociales entre ellos y el otro. La autora explica cómo la casa de los Borbones se involucró en la persecución de los Jesuitas que estaban en los

\footnotetext{
Licenciado en Historia. Aspirante a Magister en Historia de la Universidad del Valle.
} 
hospitales de caridad y otras obras de asistencia social, así como también en sus colegios y haciendas.

Ann Twinan hace además un estudio de los textos que reposan en el archivo de Indias de Sevilla y en los archivos nacionales de Hispanoamérica; entre estos textos los que más se estudian son las llamadas gracias al sacar. Para la profesora de la Universidad de Texas, las reformas sociales borbónicas tenían metas contradictorias. La pragmática sanción sobre el matrimonio (1778) desalentaba la movilidad social y racial, sin embargo las legitimaciones y el blanqueamiento promovidos oficialmente, a fin de pasar una evaluación de estas medidas, el impacto variable en la Península y en América, la transformación en el tiempo y en el proceso, muestran que eran muy coherentes y en esencia conservadoras.

Los borbones no fueron innovadores. La pragmática sanción sobre los matrimonios, las gracias al sacar y la política sobre los expósitos ya habían sido puestas a prueba en las localidades o sobre individuos, y convertidos en políticas imperiales. Tanto la ubicación de las cláusulas de blanqueamiento dentro del arancel de 1775, como los precios que se cobran, apoyan la hipótesis de que los legisladores añadieron estas medidas más con un sentido administrativo para que quedaran completas y para obtener ganancias, que para obtener una reforma social.

Cuando los historiadores evalúan las reformas borbónicas (1759 - 1808), a menudo hacen caso omiso de las medidas sociales, quizás porque éstas han parecido contradictorias, porque no han sido muy estudiadas, o porque sus objetivos no estaban en el escenario de lo social. El mérito de este libro es ayudar a comprender y entender de una manera más completa las relaciones entre las colonias y la península a finales del período colonial.

Para terminar, debe recalcarse que esta libro está muy bien escrito, su prosa es ágil y amena, se apoya en importante material documental y adicionalmente está acompañado de mapas y tablas que no solo ilustran, sino que son un componente importante del libro, en la medida en que contribuyen a ampliar, clarificar y explicar el análisis que la autora hace en los diferentes capítulos.

Podemos decir que estamos ante un trabajo bien elaborado, coherente y riguroso, con el cual se demuestra la importancia del análisis social para contribuir a clarificar los grandes problemas de Colombia y el Continente, los cuales siguen gravitando sobre la conflictiva realidad de nuestra época. 